\title{
Evaluation of Steviol Injection on Chicken Embryos: Effects on Post-hatch Development, Proportional Organ Weights, Plasma Thyroid Hormones and Metabolites
}

\author{
Mohsen Daneshyar ${ }^{1}$, Jan M.C. Geuns ${ }^{2}$, Johan G. Buyse ${ }^{3}$, Hassan Kermanshahi ${ }^{4}$, \\ Hilke Willemsen ${ }^{3}$, Zarbakht Ansari ${ }^{5}$, Eddy Decuypere ${ }^{3}$ and Nadia Everaert ${ }^{3}$ \\ ${ }^{1}$ Department of Animal Science, Faculty of Agriculture, Urmia University, Urmia, Iran \\ ${ }^{2}$ Laboratory of Functional Biology, K.U.Leuven, Kasteelpark Arenberg 31, B-3001 Leuven, Belgium \\ ${ }^{3}$ Laboratory of Livestock Physiology, Immunology and Genetics, Department of Biosystems, \\ K.U.Leuven, Kasteelpark Arenberg 30, B-3001 Leuven, Belgium \\ ${ }^{4}$ Department of Animal Science, Faculty of Agriculture, Ferdowsi University of Mashhad, Mashhad, Iran \\ ${ }^{5}$ Department of Animal Science, University of Agricultural Science and Natural Resources of Sari, Sari, Iran
}

\begin{abstract}
At day 7 of incubation, eggs were injected with high levels of steviol (1.5 and $3 \mathrm{mg}$ per egg). At hatch, no effect of steviol injection was observed on plasma thyroid hormone levels, hatchability, body weight and chick quality. Proportional liver weight of chicks receiving the highest steviol dose was significantly higher, while the proportional bursa weight of the steviol injected groups was significantly lower compared to that of the control. Moreover, plasma lactate dehydrogenase activity of chicks from the highest steviol injected group was significantly higher compared to control values. At 7 days of age, proportional liver weight of chicks of the $3 \mathrm{mg}$ steviol injected group was significantly lower compared to that of the control treatment. It is concluded that injection of a high dose of steviol has no effect on plasma thyroid hormones and has only slight and temporary metabolic effects on the chicken embryo.
\end{abstract}

Key words: chicken embryo, metabolic parameters, steviol, thyroid hormones

\section{Introduction}

Stevia (Stevia rebaudiana Bertoni) is a perennial shrub indigenous to Brazil and Paraguay where it has been used as a natural sweetener for hundreds of years. In recent years, stevia has been grown commercially and used as natural sweetener in many countries including Brazil, Paraguay, Japan, China, Korea, the United States, Canada and parts of Europe. The sweetening property of stevia and its extracts (stevioside and rebaudioside A) is well documented in humans (Mizutani and Tanaka, 2002; Geuns et al., 2004). Stevioside is the main sweet compound and dulcoside $\mathrm{A}$, steviolbioside, rebaudioside $\mathrm{A}, \mathrm{B}$, $\mathrm{C}, \mathrm{D}$ and $\mathrm{E}$ are present in lower concentrations. In Brazil, Korea and Japan, stevia leaves, stevioside and highly refined extracts are officially used as a low calorie sweetener (Mizutani and Tanaka, 2002; Kim, 2002).

Stevioside is a high-intensity sweetener that tastes about 300 times sweeter than sucrose ( $0.4 \%$ solution). In many

Received: July 4, 2009, Accepted: September 15, 2009

Released Online Advance Publication: December 10, 2009

Correspondence: Dr. N. Everaert, K.U. Leuven, Kasteelpark Arenberg 30, B-3001 Leuven, Belgium. (E-mail: nadia.everaert@biw.kuleuven.be) countries, it is used as a low calorie sweetener in a wide range of food products and beverages (Kinghorn, 2002). The advantages of stevioside as a dietary supplement for human subjects are manifold: it is stable, it is noncalorific, it maintains good dental health by reducing the intake of sugar, and it opens the possibility for use by diabetic and phenylketonuria patients and obese persons (Geuns et al., 2003a).

Steviol, the aglycone of stevioside, is one of the major metabolites of stevioside during its enzymatic hydrolysis (Hutapea et al., 1997). It has been demonstrated that stevioside is completely converted to its aglycone steviol after incubation with human colon microflora in vitro (Hutapea et al., 1997; Gardana et al., 2003), and by colon bacteria of pig in vivo (Geuns et al., 2003a) and human (Simonetti et al., 2004). In humans, part of this steviol is absorbed by the colon and transported to the liver by portal blood where it is transformed into steviol glucuronide that is filtered from the peripheral blood by the kidneys and excreted into urine (Geuns et al., 2007). In contrast, in meat type chickens and laying hens, about 21.5 and $7.3 \%$ were converted to steviol respectively (Geuns et al., 2003c). 
Many papers have been published regarding the safe use of stevioside in humans (Geuns et al., 2007) and animals (Akashi and Yokoyama, 1975; Geuns et al., 2004). The safety of steviol glycosides was confirmed by JECFA (2008) that proposed an acceptable daily intake (ADI) of 0 $-4 \mathrm{mg} / \mathrm{kg} \mathrm{BW}$ steviol equivalents. However, it is known that there are some negative effects about steviol. Steviol was mutagenic in Salmonella typhimurium TM677 (Pezzuto et al., 1985), and showed a clastogenic effect in cultured Chinese hamster lung in combination with Arochlor 1254induced liver supernatant $9000 \mathrm{~g}$ fraction (S9) (Matsui et al., 1996). Chromosome breakage was observed in mice, rats and hamsters, and a reduced ratio of polychromatic over normochromatic erythrocytes in female hamsters, mice and rats after steviol administration (Temcharoen et al., 2000). A significant decrease of maternal body weight gain and high maternal mortality was observed at 0.75 and $1.0 \mathrm{~g} \mathrm{steviol} / \mathrm{kg} \mathrm{BW} /$ day in hamsters (Wasuntarawat et al., 1998). In zebrafish embryos, $200 \mu \mathrm{M}$ steviol induced developmental delays, pericardial edema, circulatory defects and lethality (Crawford et al., 2008). Although there is some information about the negative effects of steviol on developmental stage of hamster and zebra fish, it is not clear if this is due to changes in thyroid hormone metabolism.

The embryonic stage is the most critical and sensitive period in the development of organisms. Embryos are much more susceptible to lower doses of a toxic compound as compared to the postnatal period (Geuns et al., 2003b). Chicken embryos have been used successfully as a screening technique to assess the safety of food additives, drugs, pesticides, herbicides, fungicides, and the potency of viruses. This technique differs from feeding trials in that the chemical is in direct contact with the embryo during its development and, therefore, may indicate more readily teratogenic or toxic effects.

In a previous study (Geuns et al., 2003b), injection of three doses of steviol $(0.025,0.25$ and $1.25 \mathrm{mg}$ per egg) at embryonic day (ED) 7 had no effect on day-old chick quality and proportional organ weights. However, further knowledge of plasma metabolites and thyroid hormones is lacking. The purpose of this study was to investigate the effect of higher doses of injected steviol $(1.5 \mathrm{mg}$ and $3 \mathrm{mg}$ on ED7) on chick quality, chick and organ weights (hatch and day 7) and plasma parameters such as lactate dehydrogenase ( $\mathrm{LDH}$ ) activity (as a liver toxicity indicator), total protein, glucose, total cholesterol and thyroid hormone concentration.

\section{Materials and Methods}

\section{Chemicals}

Steviol was prepared according to Minne et al. (2004) and repeatedly crystallized from methanol to a purity of over $98 \%$. Solvents of high performance liquid chromatography grade were from Acros (Geel, Belgium) $\left(\mathrm{H}_{2} \mathrm{O}\right.$, acetonitrile, $\mathrm{CHCl}_{3}$ ), BDH Chemicals (Haasrode, Belgium) (methanol, ethanol, N,N-dimethylformamide), and Bio- solve (Valkenswaard, The Netherlands) (acetone). N,Ndiisopropylamine was from Acros (Geel, Belgium), and 4-(bromomethyl)-7-methoxycoumarin was from Fluka (Bornem, Belgium).

\section{Experimental Set-Up}

The experiment was approved by the Ethical Commission for Experimental Use of Animals of the K.U.Leuven.

Two hundred fifty two fertile eggs (weighing on average $65 \mathrm{~g}$ ) from the same broiler breeder flock (Cobb) (Belgabroed, Merksplas, Belgium) were put in an incubator (PasReform, Zeddam, The Netherlands), and incubated under standard conditions $\left(\mathrm{T}=37.8^{\circ} \mathrm{C}, \mathrm{RH}=55 \%\right.$, rotation over $90^{\circ}$ once an hour).

At ED7, eggs were randomly divided into three groups, each containing 84 eggs: corn oil injected group, $1.5 \mathrm{mg}$ steviol injected and $3 \mathrm{mg}$ steviol injected group, where corn oil served as a solvent. The eggs were injected with $100 \mu \mathrm{l}$ corn oil (containing no, $1.5 \mathrm{mg}$ or $3 \mathrm{mg}$ steviol) with a pipette with a tip just going into the air cell. To avoid precipitation, solutions were kept at $40^{\circ} \mathrm{C}$. Before injection, the top of the eggs was sterilized with $70 \%$ ethanol, and a small hole was made with a needle of $18 \mathrm{G}$. After injection, the holes were sealed with tape and the eggs returned to the incubator. ED7 was chosen as a suitable moment for injection in this and previous (Geuns et al., 2003b) experiment as injection occurs then during the critical developmental stages of the embryo (organogenesis) (Willier, 1954). Steviol was injected in the air cell, since the embryo lies between the yolk and air cell at that moment (Freeman and Vince, 1974).

On ED18, eggs were candled and those with evidence of living embryos were transferred to hatchery baskets.

Chicks were reared under standard conditions until day 7. Water and a commercial starter diet $(21.5 \%$ crude protein; 2958 kcal ME) (Research Diet Services BV, Wijk Bij Duurstede, The Netherlands) were provided for ad libitum consumption. Lighting schedule provided 23 hours of light per day. The temperature was set at day-old at $34^{\circ} \mathrm{C}$ and was decreased by $1{ }^{\circ} \mathrm{C}$ every day until a final temperature of $29^{\circ} \mathrm{C}$ was reached.

\section{Sampling}

At the end of ED21, eggs that did not hatch were opened to identify infertile or dead embryos. Dead embryos were classified as early (those that died between ED1 to ED7), mid (those that died between ED8 to ED 14) and late dead embryos (those that died between ED15 to ED21). Age of mortality was determined according to Hamburger-Hamilton criteria (Hamburger and Hamilton, 1951). Hatching percentage was calculated as number of hatched chicks to fertile eggs.

At hatch, all chicks were classified according to chick quality parameters as previously described (Tona et al., 2003).

At hatch and day 7, all chicks were weighed and 15 chicks of each group were randomly selected and sacrificed by decapitation to take blood samples and to dissect and weigh organs (liver, heart, bursa and spleen). Blood 
samples were collected into heparinized tubes, stored on ice and centrifuged. Plasma was collected after centrifugation and stored at $-20^{\circ} \mathrm{C}$ until further analysis. In addition, three blood samples from chicks of the $3 \mathrm{mg}$ steviol injected group were kept at $-20^{\circ} \mathrm{C}$ for steviol determination.

\section{Measurement of Steviol}

Samples of about $50 \mathrm{mg}$ dried and pulverized blood were measured as described by Geuns et al. (2003b). The detection limit was $50 \mathrm{pg}$ of steviol per injection.

\section{Plasma Analysis}

Glucose, cholesterol, total protein concentration and lactate dehydrogenase activity of plasma were determined using the Vet Test 8008 analyzer (Idexx laboratories Inc., U.S.A). The triiodothyronine $\left(\mathrm{T}_{3}\right)$ and thyroxine $\left(\mathrm{T}_{4}\right)$ concentration in the plasma samples were determined by radioimmunoassay using the procedure described by Darras et al. (1992). $\mathrm{T}_{3}$ and $\mathrm{T}_{4}$ standards were purchased from Byk-Belga (Brussels, Belgium). All samples were analyzed in the same assay in order to avoid inter-assay variability.

\section{Statistical Analysis}

The data were subjected to one-way analysis of variance using SAS statistical package version 9 (SAS Institute Inc., Cary, NC, USA). When the overall model was statistically significant, the means were further separated using the Tukey-Kramer multiple comparison test. Significance was set at 0.05 . Data are presented as means \pm SEM. The Kolmogorov-Smirnov test, at significance level of 0.01 was used to assess the normality of the distribution of chick quality score and proportional organ weights. Normalized data in the case of abnormality were used for statistical analysis. Hatchability, cumulative dead embryos, division of chick quality scores and post-hatch mortality of treatments were compared using chi-square test.

\section{Results}

\section{Hatchability and Mortality}

There was no effect of steviol (1.5 or $3 \mathrm{mg}$ ) on the hatchability and number of dead embryos (Table 1). Post-hatch mortality did not differ between treatments $(P$ $=0.059$ ) (Table 1).

\section{Chick Quality}

There was no difference in occurrence of severe anomalies between chicks of the different treatments, as shown by the amount of chicks of quality score 100 (Table 2). The average quality score of chicks from the $1.5 \mathrm{mg}$ steviol injected group was significantly higher than that of the 3 mg steviol injected group. The steviol injected groups did however not differ from the corn oil (control) injected chicks. Moreover, chicks with a quality score lower than 100 did not differ on average between treatments (Table 2) $(P=0.057)$.

\section{Body and Proportional Organ Weights}

As shown in Table 3, at hatch there was no significant difference in mean body weight between the treatments. Proportional liver weight of chicks receiving the highest steviol dose was significantly higher compared to $1.5 \mathrm{mg}$ steviol and control treatments. Proportional bursa weight at hatch was significantly lower in both steviol treated groups compared to control group. There were no significant differences in proportional heart and spleen weight between treatments. At day 7, chicks from the $3 \mathrm{mg}$ steviol injected group were significantly heavier than chicks from the $1.5 \mathrm{mg}$ steviol injected group. However, chick weights of corn oil injected eggs did not differ from that of steviol injected groups. At day 7, proportional liver weight of chicks that were injected with $3 \mathrm{mg}$ steviol was signifi-

Table 1. Hatchability (number of chicks/number of fertile eggs), embryo mortality and post-hatch mortality (number of dead embryos or chicks) of corn oil injected, $1.5 \mathrm{mg}$ steviol and $3 \mathrm{mg}$ steviol injected groups

\begin{tabular}{lccc}
\hline \hline & $\begin{array}{c}\text { Corn oil } \\
(\mathrm{n}=84)\end{array}$ & $\begin{array}{c}1.5 \mathrm{mg} \text { Steviol } \\
(\mathrm{n}=84)\end{array}$ & $\begin{array}{c}3 \mathrm{mg} \text { Steviol } \\
(\mathrm{n}=84)\end{array}$ \\
\hline Hatchability & $56 / 78$ & $58 / 82$ & $60 / 81$ \\
& $(72 \%)$ & $(71 \%)$ & $(74 \%)$ \\
Early dead embryos (1-7 days) & 2 & 7 & 4 \\
Mid dead embryos (8-14 days) & 1 & 4 & 2 \\
End dead embryos (15-21 days) & 19 & 13 & 15 \\
Post-hatch mortality & 7 & 1 & 2 \\
\hline
\end{tabular}

Table 2. Effect of steviol injection on chick quality

\begin{tabular}{lccc}
\hline \multicolumn{1}{c}{ Quality parameters } & Corn oil & $1.5 \mathrm{mg}$ Steviol & 3 mg Steviol \\
\hline Chicks with score 100 & $4 / 20$ & $7 / 20$ & $4 / 20$ \\
Average score $(\mathrm{n}=20)$ & $89 \pm 2^{\mathrm{ab}}$ & $94 \pm 1^{\mathrm{a}}$ & $86 \pm 3^{\mathrm{b}}$ \\
Average score of chicks with score $<100$ & $86 \pm 2$ & $90.3 \pm 1$ & $83 \pm 3$ \\
\hline
\end{tabular}

Values of average quality score are mean \pm SEM, and those with different superscripts (a and $b)$ are significantly different $(P<0.05)$ 
Table 3. Body weight (g) and proportional organ weights (\%) for steviol (1.5 or $3 \mathrm{mg}$ per egg) or corn oil injected groups at hatch and day 7

\begin{tabular}{|c|c|c|c|c|c|c|}
\hline \multirow{2}{*}{ Parameters } & \multicolumn{3}{|c|}{ Hatch } & \multicolumn{3}{|c|}{ Day 7} \\
\hline & Corn oil & $1.5 \mathrm{mg}$ Steviol & $3 \mathrm{mg}$ Steviol & Corn oil & $1.5 \mathrm{mg}$ Steviol & $3 \mathrm{mg}$ Steviol \\
\hline Body weight (g) & $\begin{array}{c}45.4 \pm 0.6 \\
(\mathrm{n}=56)\end{array}$ & $\begin{array}{c}45.8 \pm 0.4 \\
(\mathrm{n}=58)\end{array}$ & $\begin{array}{c}45.1 \pm 0.4 \\
(n=60)\end{array}$ & $\begin{array}{c}134 \pm 4^{\mathrm{ab}} \\
(\mathrm{n}=33)\end{array}$ & $\begin{array}{c}132 \pm 3^{b} \\
(n=43)\end{array}$ & $\begin{array}{c}146 \pm 4^{a} \\
(n=36)\end{array}$ \\
\hline Proportional liver weight (\%) & $2.0 \pm 0.1^{\mathrm{b}}$ & $2.1 \pm 0.1^{\mathrm{b}}$ & $2.3 \pm 0.1^{\mathrm{a}}$ & $4.2 \pm 0.2^{\mathrm{a}}$ & $4.0 \pm 0.1^{\mathrm{ab}}$ & $3.6 \pm 0.1^{\mathrm{b}}$ \\
\hline Proportional heart weight $(\%)$ & $0.75 \pm 0.02$ & $0.70 \pm 0.02$ & $0.72 \pm 0.03$ & $0.85 \pm 0.04$ & $0.78 \pm 0.02$ & $0.81 \pm 0.03$ \\
\hline Proportional bursa weight $(\%)$ & $0.14 \pm 0.01^{\mathrm{a}}$ & $0.11 \pm 0.01^{\mathrm{b}}$ & $0.10 \pm 0.01^{\mathrm{b}}$ & $0.15 \pm 0.01$ & $0.16 \pm 0.01$ & $0.16 \pm 0.01$ \\
\hline Proportional spleen weight $(\%)$ & $0.043 \pm 0.001$ & $0.045 \pm 0.001$ & $0.041 \pm 0.001$ & $0.103 \pm 0.009$ & $0.107 \pm 0.006$ & $0.097 \pm 0.008$ \\
\hline
\end{tabular}

Means \pm SEM are given $(n=15$ for proportional weight), and per age, those with different superscripts $(a$ and $b)$ are significantly different $(P<0.05)$

Table 4. Effect of steviol (1.5 or $3 \mathrm{mg}$ per egg) or corn oil injection on plasma triiodothyronine $\left(T_{3}\right)$, thyroxine $\left(T_{4}\right)$ concentrations $(\mathrm{ng} / \mathrm{mL})$ and $T_{3} / T_{4}$ ratio, glucose $(\mathrm{mmol} / \mathrm{L})$, cholesterol $(\mathrm{mmol} / \mathrm{L})$ and total protein $(\mathrm{g} / \mathrm{L})$ concentrations at hatch and lactate dehydrogenase (LDH) activity at hatch and day 7

\begin{tabular}{lccc}
\hline \hline \multicolumn{1}{c}{ Parameters $^{2}$} & $\begin{array}{c}\text { Corn oil } \\
(\mathrm{n}=15)\end{array}$ & $\begin{array}{c}1.5 \mathrm{mg} \text { Steviol } \\
(\mathrm{n}=15)\end{array}$ & $\begin{array}{c}3 \mathrm{mg} \text { Steviol } \\
(\mathrm{n}=15)\end{array}$ \\
\hline $\mathrm{T}_{3}(\mathrm{ng} / \mathrm{mL})$ & $1.2 \pm 0.1$ & $1.2 \pm 0.1$ & $1.1 \pm 0.1$ \\
$\mathrm{~T}_{4}(\mathrm{ng} / \mathrm{mL})$ & $7.3 \pm 0.6$ & $8.1 \pm 0.7$ & $8.5 \pm 0.5$ \\
$\mathrm{~T}_{3} / \mathrm{T}_{4}$ ratio & $0.16 \pm 0.01$ & $0.15 \pm 0.01$ & $0.14 \pm 0.01$ \\
Glucose $(\mathrm{mmol} / \mathrm{L})$ & $12.9 \pm 0.3$ & $12.8 \pm 0.4$ & $12.8 \pm 0.1$ \\
Cholesterol $(\mathrm{mmol} / \mathrm{L})$ & $10.0 \pm 0.4$ & $9.9 \pm 0.4$ & $10.4 \pm 0.5$ \\
Total Protein $(\mathrm{g} / \mathrm{L})$ & $14.2 \pm 0.7$ & $15.1 \pm 1.2$ & $16.4 \pm 0.7$ \\
LDH activity $(\mathrm{U} / \mathrm{L})$ at hatch & $1624 \pm 62^{\mathrm{b}}$ & $1753 \pm 76^{\mathrm{ab}}$ & $1869 \pm 53^{\mathrm{a}}$ \\
LDH activity (U/L) at $7^{\text {th }}$ day of age & $1722 \pm 119$ & $1721 \pm 108$ & $1962 \pm 102$ \\
\hline
\end{tabular}

Means \pm SEM are given $(n=15)$, and those with different superscripts ( $a$ and $b)$ are significantly different $(P<0.05)$

cantly lower than that of the control group, whereas the $1.5 \mathrm{mg}$ steviol injected chicks did not differ from the other groups. There were no significant differences in proportional heart, bursa and spleen weight between treatments at this age.

\section{Plasma Hormones and Metabolites}

Results of plasma hormones and biochemical indices are shown in Table 4. There were no significant differences in $\mathrm{T}_{3}, \mathrm{~T}_{4}$ and $\mathrm{T}_{3} / \mathrm{T}_{4}$ ratio between treatments at hatch. Moreover, no significant differences in plasma glucose, total protein and cholesterol concentration were observed. Only plasma LDH activity of chicks from the $3 \mathrm{mg}$ steviol injected group was significantly higher than that of the control group at hatch while no significant differences between treatments for LDH activity were observed at 7 days of age (Table 4).

No free steviol could be detected in the plasma of day-old chicks that hatched from the steviol treated eggs.

\section{Discussion}

In ovo injection of $1.5 \mathrm{mg}$ or $3 \mathrm{mg}$ steviol at ED7 did not influence day-old chick weight or hatchability, which is in agreement with previous results (Geuns et al., 2003b), where lower doses of steviol $(0.025,0.25$ and $1.25 \mathrm{mg}$ per egg) were used. Corn oil as a solvent decreased the hatchability compared to standard incubation (normally around 90\%), as already observed by Dewitt et al. (2005). There was no negative effect of the embryonic steviol injection on the chick performance at hatch, as shown by an equal or even somewhat higher chick quality score at hatch in the steviol injected groups, confirming previous results (Geuns et al., 2003b). These results are also in agreement with another study (Oliveira-Filho et al., 1989) where no effect of concentrated leaf extracts on male fertility nor on the growth of prepubertal male rats were observed.

Since steviol was shown to delay the development of zebrafish embryos (Crawford et al., 2008) and hamster fetus (Wasuntarawat et al., 1998), it was hypothesized that steviol may affect the development by changing the thyroid hormone metabolism. However, in our study, steviol injection did not change plasma $T_{3}, T_{4}$ concentrations or $\mathrm{T}_{3} / \mathrm{T}_{4}$ ratio significantly between treatments at hatch. In contrast, supplementation of $130 \mathrm{ppm}$ of stevioside or $2 \%$ dried stevia leaves for 6 weeks in a broiler diet, lowered the $\mathrm{T}_{3}$ level with $27 \%$ or $55 \%$ respectively (Atteh et al., 2008). However, no differences in plasma thyroid hormone concentrations of prepubertal male rats were found by gastric tubing $(2 \mathrm{~m} l / \mathrm{rat})$ of crude water extracts 
from stevia leaves $(66.7 \mathrm{~g}$ dried leaves $/ 100 \mathrm{ml}$ final solution) given twice a day during 60 days (Oliveira-Filho et al., 1989). Of course, attention should be paid between the different additives (stevia leaves, stevioside or steviol), supplementation ways (oral, injection) and treatments (single embryonic injection or chronic ingestion) between experiments.

In our study, a significantly higher proportional liver weight at hatch was observed for the $3 \mathrm{mg}$ steviol injected group. This may indicate a liver challenge by steviol and is further supported by the higher level of LDH activity. Indeed, an increased LDH activity of ducks by toxic effects of fumonisin B1 in maize has been observed (Tardieu et al., 2004). Additionally, decreased bursa and spleen weights along with reduced antibody production have been observed in poults fed moniliformin in the diet ( $\mathrm{Li}$ et al., 2000). Consequently, the decreased proportional bursa weight at hatch in both steviol injected groups of our study might indicate a decreased immune function due to the embryonic exposure to steviol. However, information about immunological effects of steviol in chickens is lacking, while it is known that steviol suppressed TNF- $\alpha$ induced IL- 8 release in human colon carcinoma cell lines (Boonkaewwan et al., 2008).

Since the glucose, cholesterol and total protein concentration in the plasma of chicks before they had access to feed, did not differ between groups, it is assumed that the single prenatal steviol injection did not have an important effect on the energy metabolism of the embryos or chicks. In the same line are the results where no differences were found in glyceamia of prepubertal male rats, given extracts of stevia leaves twice a day (Oliveira-Filho et al., 1989). Chatsudthipong and Muanprasat (2009) on the other hand noted that stevioside seems to have the ability to lower plasma glucose only when these parameters are abnormally elevated. In addition, stevioside was able to lower the plasma cholesterol level after 5 weeks of treatment in the diabetic Goto-Kakizaki Rat (Jeppesen et al., 2006), while no adverse effects on lipid or glucose were reported in non-diabetic subjects, treated with stevioside for two years (Hsieh et al., 2003).

At day 7, chicks from the high steviol dose groups were significantly heavier and had significantly lower proportional liver weights, with an equal absolute liver weight. At day 7, proportional bursa and spleen weight and LDH activity did not differ between treatments, suggesting that there were only slight and temporary metabolic effects of the steviol injection during embryonic development. Noteworthy are the histopathological changes of the kidneys of pregnant hamsters receiving steviol at high doses (Wasuntarawat et al., 1998), which were the same as seen in stevioside-treated animals, that also had increased blood urea nitrogen and creatinine concentration (Toskulkao et al., 1997).

No free steviol could be detected (detection limit of 50 pg) in blood of chickens of the highest steviol dose, which is in agreement with previous results (Geuns et al., 2003 b). Since the increased LDH activity at hatch indicates that the steviol injection into the air cell was an efficient administration method for toxicological research, it might indicate that the steviol was metabolized during embryonic development. It is important to note that ED7 was chosen as a suitable moment for injection in this and previous (Geuns et al., 2003b) experiment as injection occurs then during the critical developmental stages of the embryo (organogenesis) (Willier, 1954). Steviol was injected in the air cell, since the embryo lies between the yolk and air cell at that moment (Freeman and Vince, 1974), so we can assume the injected product could directly reach the embryo.

In conclusion, no significant differences in hatchability, body weight or total quality score were found in day-old hatchlings treated with a single steviol injection during embryonic development. At hatch, chicks of the $3 \mathrm{mg}$ steviol injected group showed a higher proportional liver weight and LDH activity and lower proportional bursa weight as compared to control chicks. However, it was only a slight and temporary effect that disappeared after 1 week of raising the chicks. Therefore, it is concluded that the highest dose of steviol had a temporary metabolic effect on chicks without effects on thyroid hormone metabolism.

\section{Acknowledgments}

We thank Hilde Verlinden, Tom Struyf for their helpful technical issues and Stijn Ceunen, Amal Mohamed, Zhigang Song and Anouck Witters for their help during the research.

\section{References}

Akashi $\mathrm{H}$ and Yokoyama Y. Security of dried-leaves extracts of stevia-Report of toxicological test. Shokuhin Kogyo, 18: 34-43. 1975.

Atteh JO, Onagbesan OM, Tona K, Decuypere E, Geuns JMC and Buyse J. Evaluation of supplementary stevia (Stevia rebaudiana bertoni) leaves and stevioside in broiler diets: effects on feed intake, nutrient metabolism, blood parameters and growth performance. Journal of Animal Physiology and Animal Nutrition, 92: 640-649. 2008.

Boonkaewwan C, Ao M, Toskulkao C and Rao MC. Specific immunomodulatory and secretory activities of stevioside and steviol in intestinal cells. Journal of Agricultrural and Food Chemistry, 56: 3777-3784. 2008.

Chatsudthipong V and Muanprasat C. Stevioside and related compounds: Therapeutic benefits beyond sweetness. Pharmacology \& Thereutics, 121: 41-54. 2009.

Crawford AD, Crets W, De Witte PAM and Geuns J. Early-lifestage analysis of stevia metabolites in zebrafish: Stevioside, rebaudioside A and steviol glucuronide are non-toxic, and steviol is anti-angiogenic. In: Proceedings of the EUSTAS Stevia Symposium. pp. 139-150. 2008.

Darras VM, Visser TJ, Berghman LR and Kuhn ER. Ontogeny of type-I and type-III deiodinase activities in embryonic and posthatch chickens- relationship with changes in plasma triiodothyronine and growth-hormone levels. Comparative Biochemistry Physiology part A, 103: 131-136. 1992. 
DeWitt JC, Meyer EB and Henshel DS. Environmental toxicity studies using chickens as surrogates for wildlife: effects of vehicle volume. Archives of Environmental Contamination and Toxicology, 48: 260-269. 2005.

Freeman BM and Vince MA. Development of the avian embryo. Chapman and Hall Ltd. London. UK. 1974.

Gardana C, Simonetti P, Canzi E, Zanchi R and Pietta P. Metabolism of stevioside and rebaudioside A from Stevia rebaudiana extracts by human microflora. Journal of Agricultural and Food Chemistry, 51: 6618-6622. 2003.

Geuns JMC, Augustijns P, Mols R, Buyse JG and Driessen B. Metabolism of stevioside in pigs and intestinal absorption characteristics of stevioside, rebaudioside A and steviol. Food and Chemical Toxicology, 41: 1599-1607. 2003a.

Geuns JMC, Bruggeman V and Buyse JG. Effect of stevioside and steviol on the developing broiler embryos. Journal of Agricultural and Food Chemistry, 51: 5162-5167. 2003b.

Geuns JMC, Malheiros RD, Vera MB, Moraes VMB, Decupere EMP, Compernolle F and Buyse JG. Metabolism of stevioside by chickens. Journal of Agricultural and Food Chemistry, 51: 1095-1101. 2003c.

Geuns JMC, Buyse J, Vankeirsbilck A and Temme EHM. About the safety of stevioside used as a sweetener. In: Proceedings of the first symposium on the safety of stevioside pp. $75-83$. 2004.

Geuns JMC, Buyse J, Vankeirsbilck A and Temme EHM. Metabolism of stevioside by healthy subjects. Experimental Biology and Medicine, 232: 164-173. 2007.

Hamburger V and Hamilton HL. A series of normal stages in the development of the chick embryo. Journal of Morphology, 88: 49-92. 1951.

Hsieh MH, Chan P, Sue YM, Liu JC, Liang TH, Huang TY, Tomlinson B, Chow MS, Fao PF and Chen Y. Efficacy and tolerability of oral stevioside in patients with mild essential hypertension: a two-year, randomized, placebo-controlled study. Clinical Therapeutics, 25: 2797-2808. 2003.

Hutapea AM, Toskulkao C, Buddhasukh D, Wilairat P and Glinsukon T. Digestion of stevioside, a natural sweetener, by various digestive enzymes. Journal of Clinical Biochemistry and Nutrition, 23: 177-186. 1997.

JECFA Joint FAO/WHO Expert Committee on Food Additives, $69^{\text {th }}$ meeting, Rome, Italy, Summary and Conclusions, issued 4 July 2008. www. who.int/ipcs/food/jecfa/summaries/ summary69.pdf

Jeppesen PB, Kyrskog SE, Aggersen XJ and Hermansen K. Can stevioside in combination with a soy-based dietary supplement be a new useful treatment in type 2 diabetes? An in vivo study in the diabetic Goto-Kakizaki rat. Review of Diabetes Studies, 3: 189-199. 2006.

Kim DSHL. Synthetic investigations on steviol, stevioside, and rebaudioside $\mathrm{A}$, and their applications as starting materials. In: Stevia. The Genus Stevia. (Kinghorn AD ed.). Vol. 19 pp. 119-137. Taylor and Francis. London and New York. 2002.

Kinghorn AD. Overview. In: Stevia. The Genus Stevia. (Kinghorn
AD ed.). Vol. 19 pp. 1-17. Taylor and Francis. London and New York. 2002.

Li YC, Ledoux DR, Bermudez AJ, Fritsche K and Rottinghaus GE. The individual and combined effects of fumonisin B1 and moniliformin on performance and selected immune parameters in turkey poults. Poultry Science, 79: 871-878. 2000.

Matsui M, Matsui K, Kawasaki Y, Oda Y, Nogushi T, Kitagawa Y, Sawada M, Hayashi M, Nohmi T, Yoshihira K, Ishidate Jr. $M$ and Sofuni T. Evaluation of the genotoxicity of stevioside and steviol using six in vitro and one in vivo mutagenicity assays. Mutagenesis, 11: 573-579. 1996.

Minne VJY, Compernolle F, Toppet S and Geuns JMC. Steviol quantification at the picomole level by high-performance liquid chromatography. Journal of Agricultural and Food Chemistry, 52: 2445-2449. 2004.

Mizutani K and Tanaka O. Stevia, the genus stevia. medicinal and aromatic plants-industrial profiles. In: Use of stevia rebaudiana sweeteners in Japan (Kinghorn AD ed.). Vol 19. pp. 178-195. Taylor and Francis. London. 2002.

Oliveira-Filho RM, Uehara OA, Minetti CASA and Valle LSB. Chronic administration of aqueous extract of Stevia rebaudiana (Bert.) Bertoni in rats: endocrine effects. General Pharmacology, 20: 187-191. 1989.

Pezzuto JM, Comparde CM, Swanson SM, Nanayakkara NPD and Kinghorn AD. Metabolically activated steviol, the aglycone of stevioside, is mutagenic. Proceedings of the National Academy of Science, 82: 2478-2482. 1985.

Simonetti P, Gardana C, Bramati L and Pietta PG. Bioavailability of stevioside from Stevia rebaudiana in human volunteers: Preliminary report. In: Proceedings of the First Symposium on the Safety of Stevioside. pp. 51-62. 2004.

Tardieu D, Bailly JD, Benard G, Tran TS and Guerre P. Toxicity of maize containing known levels of fumonisin B1 during force-feeding of ducks. Poultry Science, 83: 1287-1293. 2004.

Temcharoen P, Suwannatrai M, Klongpanichpak S, Apibal S, Glinsukon T and Toskulkao C. Evaluation of the effect of steviol on chromosomal damage using micronucleus test in three laboratory animal species. Journal of the Medical Association of Thailand, 83: S101-S108. 2000.

Tona K, Bamelis F, De Ketelaere B, Bruggeman V, Moraes VMB, Buyse J, Onagbesan O and Decuypere E. Effects of storage time on spread of hatch, chick quality and chick juvenile growth. Poultry Science, 82: 736-741. 2003.

Toskulkao C, Chaturat L, Temcharoen P and Glinsukon T. Acute toxicity of stevioside, a natural sweetener, and its metabolite, steviol, in several animal species. Drug and Chemical Toxicology, 20: 31-44. 1997.

Wasuntarawat C, Emcharoen P, Toskulkao C, Mungkornkarn $\mathrm{P}$, Suttajit $\mathrm{M}$ and Glinsukon T. Developmental toxicity of steviol, a metabolite of stevioside, in the hamster. Drug and Chemical Toxicology, 21: 207-222. 1998.

Willier BH. Phases in embryonic development. Journal of Cellular and Comparative Physiology, 43 (supplement 1): 307317. 1954. 